\title{
RELATIONAL BENEFIT, KEPUASAN, DAN LOYALITAS PELANGGAN PADA BENGKEL PT HONDA DEWATA MOTOR
}

\author{
I Made Surya Prayoga ${ }^{1}$, Ni Nyoman Kerti Yasa ${ }^{1 *}$, Made Wardana ${ }^{1}$ \\ ${ }^{1}$ Program Magister Manajemen Universitas Udayana \\ Jalan P.B. Sudirman, Denpasar, Bali, 80232, Indonesia \\ *Penulis korespondensi; E-mail: manraikerti@yahoo.co.id
}

\begin{abstract}
Abstrak
Memberikan kepuasan secara konsisten kepada pelanggan dapat membuat pelanggan menjadi loyal kepada perusahaan. Sikap loyal pelanggan kepada perusahaan akan sangat membantu perusahaan untuk dapat bertahan dalam persaingan bisnis karena pelanggan merupakan sumber pendapatan dari perusahaan. Relationship marketing adalah salah satu strategi pemasaran yang bisa digunakan untuk mencapai tujuan tersebut. Melalui strategi relational benefits, perusahaan dapat memberikan manfaat atas hubungan antara perusahaan dan pelanggan. Penelitian ini dilakukan di bengkel PT Honda Dewata Motor dengan responden sebanyak 153 orang. Hasil penelitian menunjukkan bahwa confidence benefits dan social benefits berpengaruh positif dan signifikan terhadap kepuasan dan loyalitas pelanggan bengkel. Special treatment benefits tidak berpengaruh signifikan terhadap kepuasan dan loyalitas pelanggan bengkel. Selanjutnya, kepuasan pelanggan berpengaruh positif dan signifikan terhadap loyalitas pelanggan bengkel.
\end{abstract}

Kata kunci: Relational benefits, kepuasan pelanggan, loyalitas pelanggan

\begin{abstract}
Providing customer satisfaction consistently could make customers become loyal to the company. Loyal customers were the source of income and they would help the company to survive in the business competition. Relationship marketing was a strategy that can be used to achieve these goals, through relational benefits strategy. The company could give the benefit from relationship between companies and customers. This study analyzed relationship marketing in the workshop of PT Honda Dewata Motor through 153 respondents. The results show that confidence benefits and social benefits have positive effect on customer satisfaction. Special treatment benefits had no significant effect on customer satisfaction and loyalty to workshop. Customer satisfaction had positive impact to customer loyalty significantly.
\end{abstract}

Keywords: Relational benefits, customer satisfaction, customer loyalty

\section{Pendahuluan}

Perusahaan selalu dituntut untuk dapat menyesuaikan diri dengan perubahan-perubahan yang terjadi. Jika tidak dilakukan, eksistensi perusahaan akan terancam, dan perusahaan tidak akan mampu untuk bertahan di dalam persaingan yang semakin hari semakin ketat. Dalam menghadapi hal ini, perusahaan dituntut untuk mampu senantiasa memberikan kepuasaan bagi pelanggan karena pelanggan merupakan sumber pendapatan dari perusahaan. Memberikan kepuasan secara konsisten kepada pelanggan dapat membuat pelanggan menjadi loyal kepada perusahaan. Sikap loyal pelanggan kepada perusahaan akan sangat membantu perusahaan untuk dapat bertahan di dalam persaingan bisnis (Leverin \& Liljander, 2006). Loyalitas tidak dapat muncul dalam waktu yang singkat. Perusahaan harus dapat secara konsisten menjaga kepuasan pelanggan dalam jangka panjang. Memiliki pelanggan yang loyal tentu akan sangat menguntungkan bagi perusahaan (Eisingerich \& Bell, 2006).

Kepuasaan pelanggan merupakan suatu hal yang sangat krusial dalam menentukan sukses atau tidaknya suatu bisnis (Kau \& Elizabeth, 2006). Memberikan kepuasan secara konsisten kepada pelanggan bukanlah perkara mudah. Alrubaiee and Nahla (2010) berpendapat bahwa perubahaan yang terjadi kini cenderung membuat pelanggan semakin mudah dalam menentukan pilihan dan mengambil suatu keputusan. Ini dikarenakan mudahnya mendapatkan informasi membuat pelanggan semakin pintar, dan mampu mengevaluasi produk mana yang mampu memenuhi harapannya atas apa yang dijanjikan oleh pemasar dalam kegiatan komunikasi pemasaran. Menghadapi tantangan tersebut, perusahaan harus mulai melakukan penyesuaian strategi. Perusahaan yang dulunya 
lebih berfokus pada kegiatan transaksional kini harus mulai beralih pada kegiatan relationship guna mendekatkan diri dengan konsumen dan lebih mengetahui apa kebutuhan saat ini, serta dapat memberikan manfaat kepada konsumen atas hubungan yang telah dirajut oleh perusahaan dan konsumen (Hennig-Thurau et al., 2002). Menurut Palmatier, Dant, Grewal, and Evans (2006) relationship marketing adalah filosofi dalam melakukan bisnis yang berorientasi strategis, yang berfokus pada menjaga dan meningkatkan kualitas hubungan dengan pelanggan saat ini, bukan berfokus pada usaha untuk memperoleh pelanggan baru. Memberikan manfaat dari sebuah hubungan atau relational benefit sesungguhnya dapat menguntungkan kedua belah pihak, baik pelanggan maupun perusahaan (Maria-Eugenia, Gil-Saura, \& Berenguer-Contri, 2009; Amonini, McColl-Kennedy, Soutar, \& Sweeney, 2010; dan Vincent \& Cynthia, 2013). Oleh karena itu, penelitian ini memiliki tujuan untuk mengetahui pengaruh relationship benefit terhadap kepuasan dan loyalitas pelanggan.

Pemasaran hubungan atau pemasaran relasional (relationship marketing) adalah filosofi dalam melakukan bisnis yang berorientasi strategis dengan fokus pada menjaga dan meningkatkan kualitas hubungan dengan pelanggan saat ini, bukan berfokus pada usaha untuk memperoleh pelanggan baru (Zheithaml, Bitner, \& Gremler, 2006, p. 182). Filosofi ini mengasumsikan bahwa banyak konsumen dan pelanggan bisnis lebih memilih untuk memiliki hubungan yang berkelanjutan dengan satu perusahaan saja daripada harus berpindah-pindah pada perusahaan lain, selama perusahaan mampu memberikan nilai dan memenuhi harapan dari pelanggan. Menjaga pelanggan saat ini akan membuat biaya yang harus dikeluarkan oleh perusahaan akan jauh lebih sedikit dibandingkan dengan mencoba untuk menarik konsumen yang baru. Pemasar yang sukses akan bekerja dengan menggunakan strategi yang efektif untuk mempertahankan pelanggan (Ardyansyah, 2007).

Menurut Zheithaml et al. (2006, p. 183) relational benefit adalah hal yang akan dirasakan oleh pelanggan ketika telah menerima layanan dari perusahaan penyedia jasa yang memiliki nilai yang lebih tinggi dibandingkan apa yang mereka harapkan/dapatkan dari perusahaan lainnya. Ketika perusahaan mampu dengan konsisten menyampaikan nilai dari sudut pandang pelanggan, maka satu manfaat (benefit) akan dirasakan pelanggan dengan lebih jelas yang akan mendorong mereka untuk mempertahankan hubungan. Relational benefit terdiri atas confidence benefits, social benefits, dan special treatment benefits (MariaEugenia et al., 2009).
Pelanggan yang merasa mendapatkan nilai atau manfaat (relational benefit) dari program relationship marketing, akan merasakan suatu kepuasan. Kotler (2006, p. 61) mengemukakan bahwa kepuasan pelanggan adalah tingkat perasaan seseorang setelah membandingkan antara kinerja yang dirasakan dengan harapannya. Pelanggan mengalami berbagai tingkat kepuasan dan ketidakpuasan, setelah mengalami atau merasakan masing-masing jasa sesuai dengan sejauh mana harapan mereka terpenuhi atau terlampaui (Ndubisi \& Chan, 2005; Kim, 2005).

Selanjutnya, perasaan puas dari konsumen akan memiliki pengaruh terhadap loyalitasnya. Menurut Hurriyati (2005, p. 129) loyalitas mengacu pada wujud perilaku dari unit-unit pengambilan keputusan untuk melakukan pembelian secara terus menerus terhadap produk suatu perusahaan yang dipilih. Menurut Leverin and Liljander (2006); Maria-Eugenia et al. (2009), loyalitas pelanggan ditunjukkan oleh perilaku menjadikan perusahaan sebagai pilihan yang pertama, akan selalu menggunakan produk perusahaan, selalu bercerita hal-hal positif tentang produk perusahaan, dan tidak akan beralih kepada pesaing.

\section{Kerangka Konsep}

Dalam menyusun model pengaruh konstruk relational benefit dengan konstruk kepuasan serta loyalitas pelanggan, penelitian ini mengadopsi dan mengadaptasi beberapa model penelitian yang relevan dengan topik ini. Model penelitian mengenai relational benefit yang digolongkan melalui tiga buah konstruk yaitu confidence benefits, social benefits, dan special treatment benefits yang merupakan adopsi dari penelitian yang dilakukan oleh Hennig-Thurau et al. (2002). Penggolongan konstruk relational benefit menjadi confidence benefits, social benefits, dan special treatment benefits juga dilakukan oleh MariaEugenia et al. (2009); Dimitriadis (2010); Yen and Gwinner, (2003); Kinard and Capella (2006); Molina, Martin-Consuegra, and Esteban (2007); Zheithaml et al. (2006, p.184).

Confidence benefits merupakan kemampuan perusahaan dalam mengurangi kecemasan pelanggan. Hal ini menyebabkan pelanggan memberikan kepercayaan dan keyakinan kepada perusahaan penyedia jasa. Jika dikaitkan dengan objek penelitian ini yaitu bengkel, maka confidence benefits menjadi hal yang penting bagi pelanggan bengkel. Ini untuk dapat merasa nyaman dan segala kecemasannya berkurang karena kepercayaan dan keyakinan terhadap reputasi dari perusahaan.

Social Benefit merupakan manfaat sosial ketika perusahaan melalui karyawan mampu menjalin hu- 
bungan yang baik dengan pelanggan. Zheithaml et al. (2006, p. 184) menyatakan bahwa hubungan yang baik akan membuat pelanggan merasa lebih nyaman dalam beriteraksi. Hubungan personal menjadi penting bagi karyawan bengkel pada perusahaan yang menjadi objek pada penelitian, agar dapat membangun hubungan personal yang baik dengan pelanggan.

Special treatment benefits merupakan sebuah bentuk perlakuan istimewa bagi pelanggan berupa pelayanan yang berbeda dari pelanggan lain pada umumnya (Hennig-Thurau et al., 2002). Berkaitan dengan lokasi penelitian ini, maka perusahaan harus dapat memberikan pelayanan di luar manfaat inti dari produk yang digunakan pelanggan, agar pelanggan nantinya mendapatkan hal yang berbeda dan lebih ketika menggunakan produk di perusahaan tersebut.

Kalau suatu perusahaan mampu mengembangkan program relationship marketing dengan baik, maka program ini mampu memberikan relational benefit bagi pelanggannya. Pelanggan akan merasa puas dan pada akhirnya menjadi loyal. Dalam penelitian yang berkaitan dengan relationship marketing, kepuasan pelanggan merupakan konstruk dari relational quality (Leverin \& Liljander, 2006; Alrubaiee \& Nahla, 2010). Relational quality akan muncul ketika relational benefit telah didapatkan, dan muara dari hubungan tersebut adalah relational outcomes (Hennig-Thurau et al., 2002).
Outcomes dari program relationship marketing juga berupa loyalitas pelanggan. Selain loyalitas, terdapat word of mouth yang juga merupakan bagian dari relational outcomes (Hennig-Thurau et al., 2002). Namun, karena di dalam indikator loyalitas sudah terdapat unsur word of mouth, yaitu word of mouth dalam bentuk positif, maka konstruk word of mouth tidak dimasukan dalam penelitian ini (Semadi, Suprapti, \& Nurchaya, 2010).

Berdasarkan beberapa penelitian serta kajian teori, maka dapat disusun kerangka konsep penelitian seperti pada Gambar 1.

\section{Hipotesis Penelitian}

Penelitian yang dilakukan oleh Semadi et al. (2010) yang meneliti pengaruh confidence benefits terhadap kepuasan nasabah bank menunjukkan hasil yang signifikan dan positif. Ardyansyah (2007) meneliti tentang pengaruh confidence benefits terhadap kepuasan pelanggan perusahaan distributor menemukan hasil yang positif dan signifikan. Penelitian lainnya yang menunjukkan hasil yang serupa adalah penelitian Hennig-Thurau et al. (2002), Yen and Gwinner (2003), Kinard and Capella (2006), Molina et al. (2007), dan Prayustika dan Adriani (2010). Semua penelitian ini menunjukkan bahwa confidence benefits berpengaruh positif dan signifikan terhadap kepuasan pelanggan. Berdasarkan hasil kajian empiris tersebut dapat disusun hipotesis yakni $H_{I}$ : Confidence benefits berpengaruh positif dan signifikan terhadap kepuasan pelanggan.

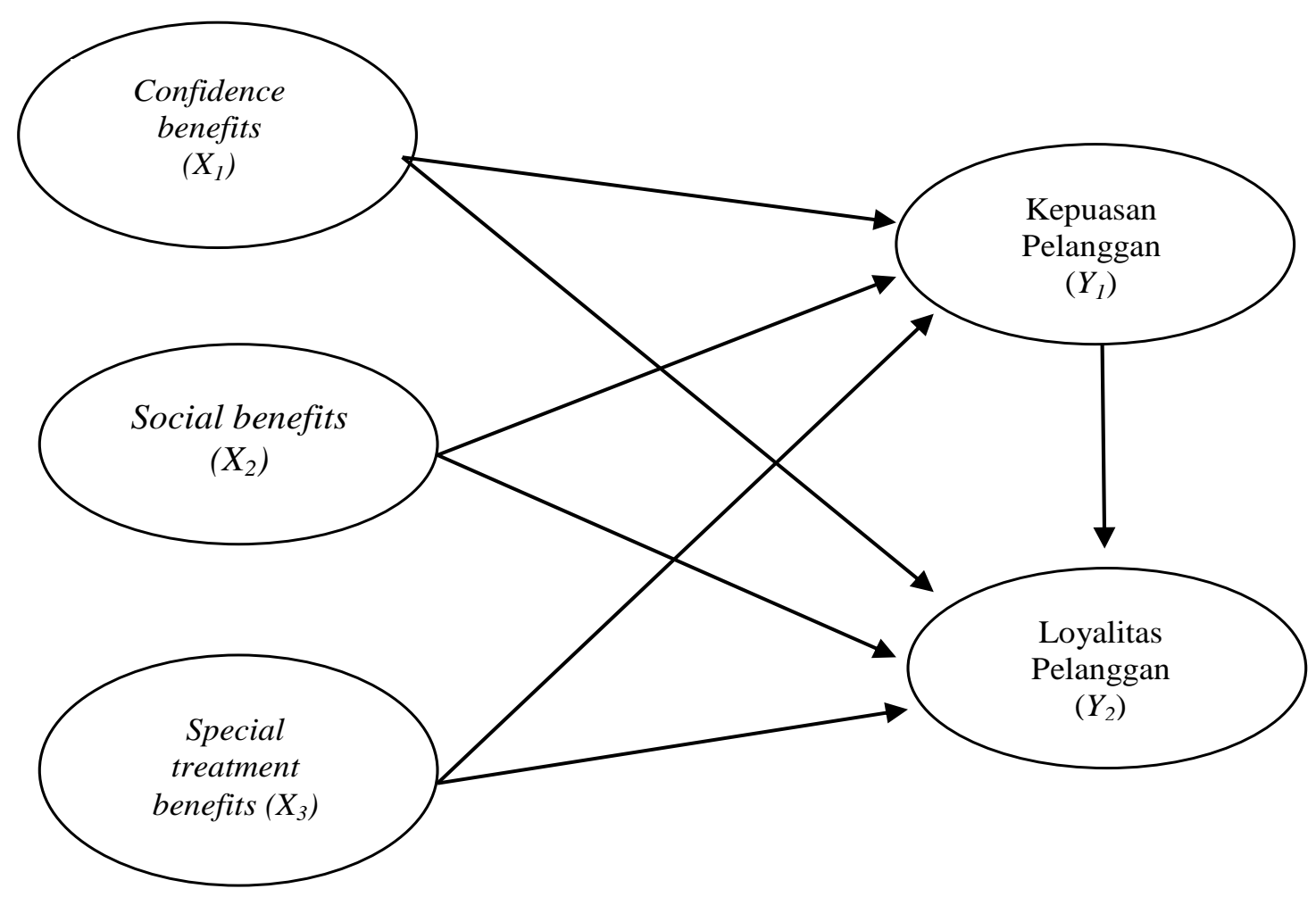

Gambar 1. Kerangka Konsep Penelitian 
Social Benefit merupakan manfaat sosial ketika perusahaan melalui karyawan mampu menjalin hubungan yang baik dengan pelanggan. Zheithaml et al. (2006, p. 184) menyatakan bahwa hubungan yang baik akan membuat pelanggan merasa lebih nyaman dalam beriteraksi. Navarro, Iglesias, and Torres (2004), Ardyansyah (2007), dan Semadi et al. (2010) yang meneliti tentang pengaruh social benefit terhadap kepuasan pelanggan menemukan hasil bahwa social benefit yang semakin tinggi mampu meningkatkan kepuasan pelanggan secara signifikan. Berdasarkan hasil kajian empiris tersebut, maka dapat dibangun hipotesis yakni $\mathrm{H}_{2}$ : Social benefits berpengaruh positif dan signifikan terhadap kepuasan pelanggan.

Special treatment benefits merupakan sebuah bentuk perlakuan istimewa bagi pelanggan berupa pelayanan yang berbeda dari pelanggan lain pada umumnya (Hennig-Thurau et al., 2002). Penelitian yang dilakukan oleh Ardyansyah (2007); Prayustika dan Andriani (2010) yang meneliti mengenai pengaruh special treatment benefits terhadap kepuasan pelanggan Balibeach Golf Curse menunjukkan bahwa konstruk special treatment benefits secara signifikan berpengaruh positif terhadap kepuasan pelanggan. $H_{3}$ : Special treatment benefits berpengaruh positif dan signifikan terhadap kepuasan pelanggan.

Adanya pengaruh positif dan signifikan confidence benefits terhadap loyalitas pelanggan dikemukakan oleh Hennig-Thurau et al. (2002); Yen and Gwinner (2003); Kinard and Capella (2006); MariaEugenia et al. (2009); serta Semadi et al. (2010). Pelanggan yang merasa mendapatkan confidence benefits akan menjadi loyal terhadap layanan perusahaan tersebut. Berdasarkan beberapa kajian empiris tersebut, maka dapat disusun hipotesis yakni $\mathrm{H}_{4}$ : Confidence benefits berpengaruh positif dan signifikan terhadap loyalitas pelanggan

Temuan penelitian yang menyatakan bahwa terdapat pengaruh positif dan signifikan social benefits terhadap loyalitas dikemukakan oleh Macintosh and Lockshin (1997), Hennig-Thurau et al. (2002); dan Navarro et al. (2004). Berdasarkan tiga hasil penelitian tersebut, dapat disusun hipotesis yakni $H_{5}$ : Social benefits berpengaruh positif dan signifikan terhadap loyalitas pelanggan.

Penelitian yang menemukan adanya pengaruh positif dan signifikan special treatment benefits terhadap loyalitas dikemukakan antara lain oleh Maria-Eugenia et al. (2009); Yen and Gwinner (2003); Prayustika dan Adriani (2010); Ardyansyah (2007). Penelitipeneliti ini menemukan bahwa semakin tinggi special treatment benefits yang dirasakan pelanggan mampu meningkatkan loyalitas pelanggan terhadap perusahaan. Berdasarkan hasil kajian empiris ini, maka dapat disusun hipotesis yakni $H_{6}$ : Special treatment benefits berpengaruh positif dan signifikan terhadap loyalitas pelanggan.

Penelitian tentang pengaruh kepuasan terhadap loyalitas pelanggan diantaranya dikembangkan oleh Navarro et al. (2004), Ardyansyah (2007), Yen and Gwinner (2003); Hennig-Thurau et al. (2002); Yen, Liu, and Tuan (2009); Prayustika dan Andriani (2010); Semadi et al. (2010). Keseluruhan hasil riset tersebut mengemukakan bahwa kepuasan secara signifikan berpengaruh positif terhadap loyalitas pelanggan. Hubungan antara kepuasan dan loyalitas adalah saat konsumen mencapai tingkat kepuasan tertinggi akan menimbulkan ikatan emosi yang kuat dan komitmen jangka panjang dengan merek perusahaan. Konsep tersebut menunjukkan bahwa adanya pengaruh kepuasan terhadap kesetiaan konsumen. Hipotesisnya adalah $H_{7}$ : Kepuasan pelanggan berpengaruh positif dan signifikan terhadap loyalitas pelanggan.

\section{Metode Penelitian}

Penelitian ini dilakukan di bengkel PT Honda Dewata Motor yang beralamat di Jalan Imam Bonjol 104, Denpasar, Bali dengan mengambil subjek para pelanggan bengkel PT Honda Dewata Motor. Pengambilan sampel dalam penelitian ini menggunakan metode purposive sampling. Menurut Sugiyono (2009) purposive sampling adalah teknik penentuan sampel dengan pertimbangan tertentu. Dalam penelitian ini yang menjadi pertimbangan adalah responden yang pernah menggunakan layanan bengkel PT Honda Dewata Motor minimal enam bulan terakhir, karena jangka waktu tersebut diangggap masih relevan untuk menjawab kuesioner. Pertimbangan lainnya adalah responden yang berumur 17-60 tahun dan memiliki tingkat pendidikan terakhir SMA/sederajat. Hal ini dikarenakan pada rentang usia dan tingkat pendidikan tersebut responden mampu memahami dan mampu menjawab pertanyaan dalam kuesioner sesuai dengan pengalaman yang diperoleh.

Jumlah anggota sampel atau besarnya sampel (sampel size) ditetapkan dengan pertimbangan yang menyatakan, bahwa banyaknya sampel dapat ditentukan dari jumlah indikator dalam model dikalikan lima hingga 10 (Solimun, 2005). Oleh karena jumlah indikator dalam penelitian ini adalah 22 item, maka ukuran sampel menjadi antara 110-220. Berdasarkan pertimbangan kepraktisan dan biaya, jumlah sampel yang digunakan adalah 153. Identifikasi variabel dan indikator variabel disajikan dalam Tabel 1 . 
Tabel 1

Identifikasi Variabel dan Indikator Variabel Penelitian

\begin{tabular}{|c|c|c|c|c|}
\hline $\begin{array}{c}\text { Jenis } \\
\text { konstruk }\end{array}$ & $\begin{array}{l}\text { Nama konstruk } \\
\text { (Sumber) }\end{array}$ & $\begin{array}{l}\text { Jumlah } \\
\text { indikator }\end{array}$ & Kete & Simbol \\
\hline \multirow[t]{3}{*}{ Eksogen } & $\begin{array}{l}\text { - Confidence benefits } \\
\text { (Hennig-Thurau et al., 2002; Kinard } \\
\text { \& Capella, 2006; Maria-Eugenia et } \\
\text { al., 2009) }\end{array}$ & 4 & $\begin{array}{l}\text { 1) Kepercayaan terhadap karyawan } \\
\text { 2) Kepercayaan terhadap reputasi } \\
\text { 3) Keandalan karyawan } \\
\text { 4) Ketepatan janji pada pelanggan atas jasa }\end{array}$ & $\begin{array}{l}X_{1.1} \\
X_{1.2} \\
X_{1.3} \\
X_{1.4}\end{array}$ \\
\hline & $\begin{array}{l}\text { - Social benefits } \\
\text { (Dimitriadis, 2010; Kinard \& } \\
\text { Capella, 2006; Maria-Eugenia et } \\
\text { al., 2009) } \\
\text { - Special treatment benefits }\end{array}$ & 4 & $\begin{array}{l}\text { 1) Perlakuan personal yang baik } \\
\text { 2) Hubungan pertemanan } \\
\text { 3) Pengenalan Identitas konsumen oleh karyawan } \\
\text { 4) Keakraban konsumen dengan karyawan } \\
\text { bengkel. }\end{array}$ & $\begin{array}{l}X_{2.1} \\
X_{2.2} \\
X_{2.3}\end{array}$ \\
\hline & $\begin{array}{l}\text { (Maria-Eugenia et al., 2009; } \\
\text { Hennig-Thurau et al., 2002; } \\
\text { Dimitriadis, 2010) }\end{array}$ & 5 & $\begin{array}{l}\text { 1) Prioritas dalam list } \\
\text { 2) Potongan harga } \\
\text { 3) Layanan yang berbeda } \\
\text { 4) Harga yang berbeda } \\
\text { 5) Pelayanan yang lebih lengkap }\end{array}$ & $\begin{array}{l}X_{3.1} \\
X_{3.2} \\
X_{3.3} \\
X_{3.4} \\
X_{3.5}\end{array}$ \\
\hline \multirow[t]{2}{*}{ Endogen } & $\begin{array}{l}\text { - Kepuasan pelanggan } \\
\text { (Ndubisi \& Chan, 2005; Kim, 2005) } \\
\text { - Loyalitas pelanggan } \\
\text { (Leverin \& Liljander, 2006; Maria- } \\
\text { Eugenia et al., 2009) }\end{array}$ & 5 & $\begin{array}{l}\text { 1) Puas dengan layanan } \\
\text { 2) Pengalaman setelah mendapatkan layanan } \\
\text { 3) Puas dengan perlakuan perusahaan } \\
\text { 4) Keputusan yang tepat } \\
\text { 5) Puas dengan keseluruhan layanan }\end{array}$ & $\begin{array}{l}Y_{1.1} \\
Y_{1.2} \\
Y_{1.3} \\
Y_{1.4} \\
Y_{1.5}\end{array}$ \\
\hline & & 4 & $\begin{array}{l}\text { 1) Menggunakan kembali } \\
\text { 2) Pilihan utama } \\
\text { 3) Tidak akan beralih } \\
\text { 4) Merekomendasikan bengkel }\end{array}$ & $\begin{array}{l}Y_{2.1} \\
Y_{2.2} \\
Y_{2.3} \\
Y_{2.4}\end{array}$ \\
\hline
\end{tabular}

\section{Metode Analisis Data}

Metode analisis yang digunakan untuk menganalisis data adalah Structural Equation Modeling (SEM). Menurut Ferdinand (2002, p. 70), SEM merupakan alat atau teknik analisis data yang terdiri atas dua tahap dasar yaitu tahap model pengukuran (Measurement Model) melalui Confirmatory Faktor Analysis dan tahap persamaan struktural model (Structural Equation Model). Tujuan utamanya adalah untuk menguji kesesuaian model tersebut (fit) dengan data yang sah. Data dalam penelitian ini dianalisis dengan menggunakan Structural Equation Modeling (SEM) dengan aplikasi software Analysis Moment of Structure (AMOS) 16.

\section{Hasil Penelitian dan Pembahasan}

\section{Tahap Analisis Model Persamaan Struktural}

Setelah model dianalisis melalui Confirmatory Faktor Analysis, diketahui bahwa masing-masing variabel dapat digunakan untuk mendefinisikan sebuah konstruk laten, maka model tersebut dapat dianalisis. Pengujian untuk model SEM dilakukan pada indeks-indeks Goodness of Fit. Salah satu alat uji yaitu Chi square bersifat sangat sensitif terhadap be- sarnya sampel. Nilai Chi square merupakan alat uji untuk mengukur overall fit. Hasil uji Chi square dipandang baik jika nilainya semakin rendah (Ferdinand, 2002, p. 55).

Kelemahan dari alat uji Chi square perlu diatasi Salah satunya dengan menggunakan alat uji Root Mean Square of Approximation (RMSEA) yang lebih independen terhadap ukuran sampel yang digunakan. RMSEA merupakan uji kesesuaian close fit, tidak seperti Chi square yang merupakan uji kesesuaian exact fit. Jadi, uji kesesuaian yang exact fit kurang realistis bila dibandingkan dengan uji kesesuaian yang close fit karena lebih realistis untuk mengukur tingkat aplikasi model terhadap data. Selain RMSEA, indeks Goodness of Fit Indeks (GFI), Tucker Lewis Index (TLI) juga sangat dianjurkan untuk dipergunakan karena indeks ini tidak sensitif terhadap besarnya sampel dan kurang dipengaruhi oleh kerumitan suatu model. Hasil analisis dari model struktural penelitian dapat dilihat pada Gambar 2.

Hasil uji kelayakan model struktural secara ringkas ditampilkan pada Tabel 2. Pada tabel tersebut ditunjukkan bahwa semua konstruk sudah memenuhi kriteria goodness of fit yang telah ditetapkan. Nilai GFI dan AGFI walaupun masih sedikit di bawah kriteria yang ditentukan, namun kondisi ini masih bisa diterima karena nilai GFI dan AGFI sudah mendekati 0,90 sehingga model sudah bisa dikatakan fit. Pertim- 


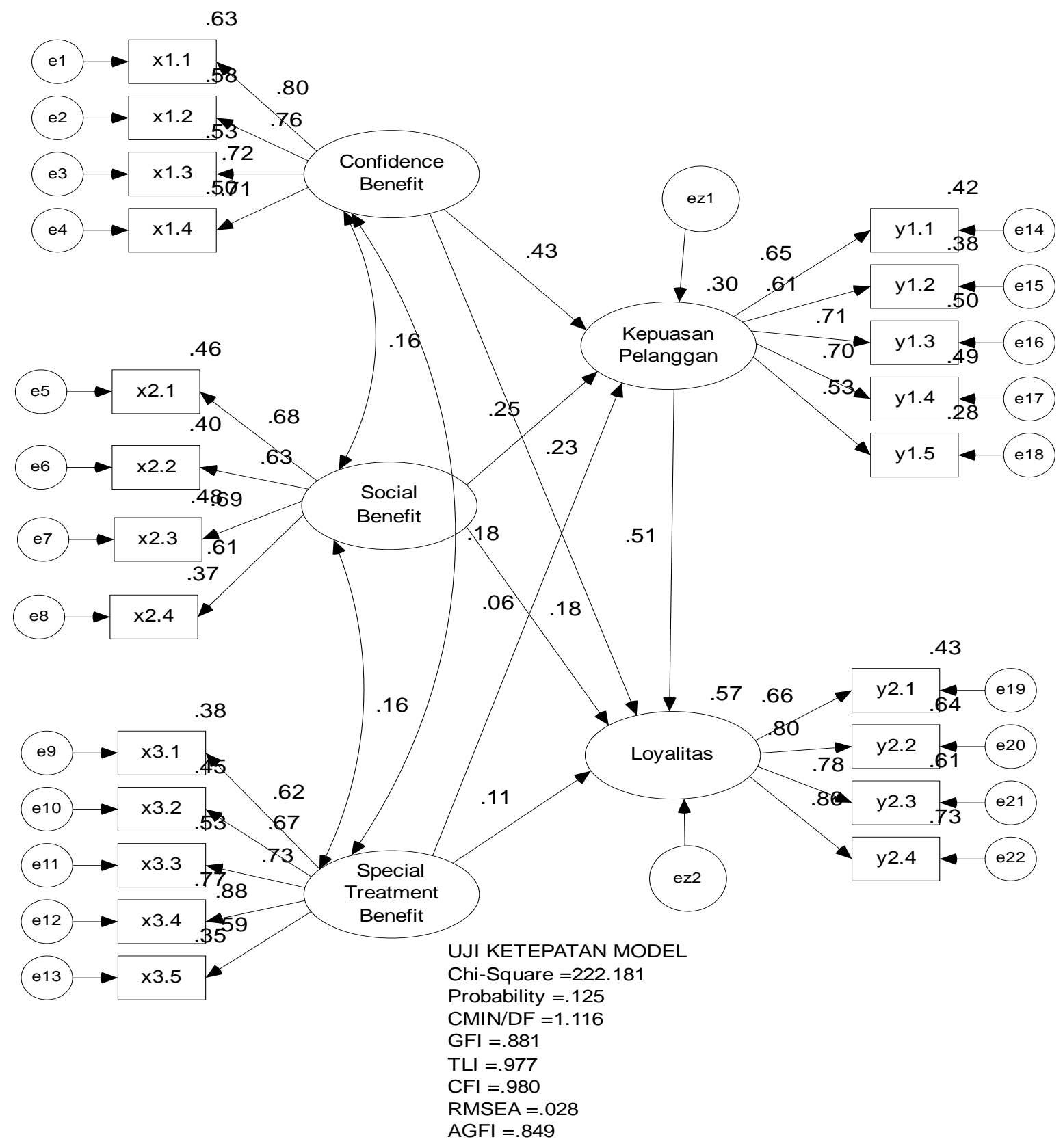

Gambar 2. Hasil Analisis Model Struktural

bangan lainnya adalah nilai probabilitas sebesar 0,125 sudah jauh di atas kriteria yang ditentukan. Hasil uji hipotesis ditunjukkan pada Tabel 3.

Berdasarkan Tabel 3, dapat dilihat bahwa dari tujuh hipotesis yang telah diuji secara keseluruhan terdapat lima hipotesis yang diterima yaitu konstruk confidence benefits berpengaruh positif dan signifikan terhadap konstruk kepuasan dengan nilai koefisien 0,431. Konstruk social benefits yang berpengaruh positif dan signifikan terhadap konstruk kepuasan karena memiliki $p$ value di bawah 0,05 . Konstruk confidence benefits juga berpengaruh positif dan signifikan terhadap konstruk loyalitas dengan nilai koefisien sebesar 0,231. Konstruk social benefits yang berpengaruh positif dan signifikan terhadap konstruk loyalitas dengan koefisien 0,176 dan $p$ value 0,48. Konstruk kepuasan juga berpengaruh positif dan signifikan terhadap konstruk loyalitas dengan nilai koefisien 0,506.

Dua hipotesis lainnya yang diuji hipotesisnya tidak dapat diterima. Konstruk special treatment benefits memiliki pengaruh positif namun tidak signifikan terhadap konstruk kepuasan karena memiliki $p$ value di atas 0,05 yaitu sebesar 0,053. Hubungan konstruk special treatment benefits terhadap konstruk loyalitas yang memiliki $p$ value sebesar 0,152 . 
Tabel 2

Uji Kelayakan Model Struktural

\begin{tabular}{lccc}
\hline \multicolumn{1}{c}{ Goodness of Fit Index } & Cut-off Value & Model & Keterangan \\
\hline$X^{2}$ - Chi- Square & Diharapkan nilai lebih kecil & 222,181 & Baik \\
Significance Probability & $\geq 0,05$ & 0,125 & Baik \\
CMIN/DF & $\leq 2,00$ & 1,116 & Baik \\
GFI & $\geq 0,90$ & 0,881 & Marginal \\
AGFI & $\geq 0,90$ & 0,849 & Marginal \\
TLI & $\geq 0,95$ & 0,977 & Baik \\
CFI & $\geq 0,95$ & 0,980 & Baik \\
RMSEA & $\leq 0,08$ & 0,028 & Baik \\
\hline
\end{tabular}

Tabel 3

Hasil Pengujian Hipotesis Penelitian

\begin{tabular}{lcccc}
\hline & Hubungan Kostruk & Koefisien & $p$ & Keterangan \\
\hline Kepuasan & $\leftarrow$ Confidence Benefits & 0,431 & $* * *$ & Hipotesis Diterima \\
Kepuasan & $\leftarrow$ Social Benefits & 0,255 & 0,015 & Hipotesis Diterima \\
Kepuasan & $\leftarrow$ Special Treatment Benefits & 0,058 & 0,530 & Hipotesis Ditolak \\
Loyalitas & $\leftarrow$ Confidence Benefits & 0,231 & 0,013 & Hipotesis Diterima \\
Loyalitas & $\leftarrow$ Social Benefits & 0,176 & 0,048 & Hipotesis Diterima \\
Loyalitas & $\leftarrow$ Special Treatment Benefits & 0,108 & 0,152 & Hipotesis Ditolak \\
Loyalitas & $\leftarrow$ Kepuasan & 0,506 & $* * *$ & Hipotesis Diterima \\
\hline
\end{tabular}

\section{Pembahasan}

Berdasarkan seluruh hasil penelitian terutama hasil pengujian hipotesis, maka dapat dijelaskan pengaruh dari konstruk eksogen yang terdiri dari confidence benefits, social benefits, special treatment benefits terhadap variabel endogen yaitu kepuasan dan loyalitas konsumen.

Berdasarkan hasil penelitian, dapat dijelaskan bahwa confidence benefits berpengaruh positif dan signifikan terhadap kepuasan pelanggaan PT Honda Dewata Motor. Artinya, bahwa confidence benefits atau manfaat kepercayaan yang meliputi reputasi perusahaan, keandalan karyawan, ketepatan janji perusahaan, dan kepercayaan terhadap karyawan bengkel, telah mampu membuat pelanggan PT Honda Dewata Motor puas. Selain itu, berdasarkan hasil penelitian juga dapat disimpulkan bahwa semakin baik manfaat kepercayaan yang diperoleh atau confidence benefits, maka kepuasan yang akan dirasakan oleh pelanggan PT Honda Dewata Motor akan semakin baik juga. Hal ini sejalan dengan studi yang dilakukan oleh Ardyansyah (2007); Hennig-Thurau et al. (2002); Yen and Gwinner (2003); Semadi et al. (2010), Molina et al. (2007), Prayustika dan Adriani (2010); Kinard and Capella (2006).

Berdasarkan hasil penelitian, dapat dijelaskan bahwa social benefits berpengaruh positif dan signifikan terhadap kepuasan pelanggaan PT Honda Dewata
Motor karena memiliki nilai $p$ di bawah 0,050. Artinya, bahwa semakin baik manfaat sosial yang diperoleh atau social benefits, maka kepuasan yang akan dirasakan oleh pelanggan PT Honda Dewata Motor akan semakin baik juga. Hasil penelitian ini juga sesuai dengan studi yang dilakukan oleh Ardyansyah (2007); Semadi et al. (2010); Navarro et al. (2004).

Berdasarkan hasil penelitian, dapat dijelaskan bahwa special treatment benefits berpengaruh tidak signifikan terhadap kepuasan pelanggaan PT Honda Dewata Motor karena memiliki nilai $p$ di atas 0,050 . Artinya, bahwa special treatment benefits atau manfaat perlakuan istimewa tidak menjadi faktor penting dalam menentukan kepuasan pelanggan PT Honda Dewata Motor. Perlakuan istimewa yang perusahaan berikan tidak mampu memberikan kepuasan kepada para pelangganya, sehingga perlu dikaji kembali apakah tindakan-tindakan perusahaan dalam memberikan perlakuan istimewa sudah tepat sasaran dan tetap memperhatikan efektivitas dari strategi tersebut. Temuan dari penelitian ini tidak sejalan dengan hasil studi yang dilakukan oleh Ardyansyah (2007); Prayustika dan Adriani (2010). Namun, pengaruh konstruk special treatment benefits yang tidak signifikan terhadap konstruk kepuasan sejalan dengan beberapa studi yang dilakukan oleh peneliti lainnya, antara lain Molina et al. (2007), Kinard and Capella (2006), Yen and Gwinner (2003), Hennig-Thurau et al. (2002).

Berdasarkan hasil penelitian, dapat dijelaskan bahwa confidence benefits berpengaruh positif dan 
signifikan terhadap loyalitas pelanggaan PT Honda Dewata Motor. Artinya, bahwa confidence benefits atau manfaat kepercayaan yang meliputi reputasi perusahaan, keandalan karyawan, ketepatan janji perusahaan dan kepercayaan terhadap karyawan bengkel, telah mampu membuat pelanggan PT Honda Dewata Motor menjadi loyal. Selain itu, berdasarkan hasil penelitian juga dapat dijelaskan bahwa semakin baik manfaat kepercayaan yang terjalin atau confidence benefits maka loyalitas pelanggan PT Honda Dewata Motor akan semakin baik juga. Hasil temuan ini sesuai dengan studi yang dilakukan oleh Kinard and Capella (2006), Yen and Gwinner (2003) Maria-Eugenia et al. (2009); Hennig-Thurau et al. (2002).

Berdasarkan hasil penelitian, dapat dijelaskan bahwa social benefits berpengaruh positif dan signifikan terhadap loyalitas pelanggaan PT Honda Dewata Motor. Artinya bahwa semakin baik manfaat sosial yang terjalin atau social benefits, maka loyalitas pelanggan PT Honda Dewata Motor akan semakin baik juga. Hasil penelitian ini juga sejalan dengan studi yang dilakukan oleh Navarro et al. (2004); HennigThurau et al. (2002); Semadi et al. (2010).

Berdasarkan hasil penelitian, dapat dijelaskan bahwa special treatment benefits berpengaruh tidak signifikan terhadap kepuasan pelanggan PT Honda Dewata Motor karena memiliki nilai $p$ di atas 0,050. Artinya, bahwa special treatment benefits atau manfaat perlakuan istimewa bukan merupakan hal yang vital dalam menciptakan loyalitas pelanggan PT Honda Dewata Motor. Temuan dari penelitian ini sesuai dengan studi yang dilakukan oleh Kinard and Capella (2006); Hennig-Thurau et al. (2002); Semadi et al. (2010); Delcourt, Gremler, Van Riel, \& Van Birgelen (2013). Namun, Hasil dari penelitian ini tidak sesuai dengan hasil penelitian Ardyansyah (2007); Yen and Gwinner (2003), Prayustika dan Adriani (2010) dan Maria-Eugenia et al. (2009).

Hasil pengujian hipotesis menunjukkan bahwa kepuasan pelanggan PT Honda Dewata Motor berpengaruh positif dan signifikan terhadap loyalitas karena nilai $p$ berada di bawah 0,050 .

Hal ini menunjukkan bahwa semakin tinggi tingkat kepuasan pelanggan PT Honda Dewata Motor, maka akan semakin tinggi juga tingkat loyalitas pelangggan PT Honda Dewata Motor. Hasil temuan ini sejalan dengan studi beberapa peneliti, diantaranya adalah Hennig-Thurau et al. (2002); Navarro et al. (2004); Yen and Gwinner (2003); Yen et al. (2009); Ardyansyah (2007); Prayustika dan Adriani (2010), dan Gaur, Xu, Quazi, and Nandi (2011).

\section{Simpulan dan Implikasi}

Simpulan yang dapat dikemukakan berdasarkan hasil penelitian yang telan di bahas di bagian sebelumnya. Confidence benefits atau manfaat kepercayaan berpengaruh positif dan signifikan terhadap kepuasan pelanggan PT Honda Dewata Motor. Hal ini menunjukkan bahwa semakin baik manfaat kepercayaan yang didapatkan pelanggan dari perusahaan, akan berbanding lurus dengan tingkat kepuasaan pelanggan. Berdasarkan penilaian pelanggan pada indikator-indikator confidence benefits, perusahaan mendapatkan penilaian yang baik karena nilai. Jadi dapat disimpulkan hasil yang baik dari penilaian konsumen terhadap confidence benefits akan berpengaruh signifikan kepada kepuasan pelanggan. Social benefits juga berpengaruh positif dan signifikan terhadap kepuasan pelanggan PT Honda Dewata Motor. Hasil penilaian pelanggan juga menunjukkan hasil yang berada pada rentang nilai baik, sehingga dapat disimpulkan manfaat pertemanan atau sosial yang diberikan oleh perusahaan berpengaruh signifikan kepada kepuasan pelanggan PT Honda Dewata Motor. Special treatment benefits tidak semua indikator yang berada di dalamnya mampu memberikan nilai yang baik. Di samping itu, hasil penelitian menunjukkan bahwa walaupun special treatment benefits memberikan hasil yang positif kepada kepuasan pelanggan namun belum signifikan.

Pengaruh dari ketiga relational benefits yang ada terhadap loyalitas pelanggan menunjukkan hasil yang serupa. Hanya konstruk confidence benefits dan social benefits yang menunjukkan nilai yang signifikan, sedangkan konstruk special treatment benefits menunjukkan hasil yang positif namun tidak signifikan. Hal ini menjelaskan bahwa ketiga konstruk sama-sama menunjukkan hasil yang positif, dimana relational benefits yang baik akan memberikan efek yang berbanding lurus dengan loyalitas pelanggan PT Honda Dewata Motor. Hanya konstruk confidence benefits dan social benefits yang mampu memberikan hasil signifikan. Kepuasan pelanggan PT Honda Dewata Motor berpengaruh positif terhadap loyalitas pelanggan. Semakin baik tingkat kepuasan yang dirasakan pelanggan PT Honda Dewata Motor, maka akan semakin loyal pelanggan tersebut. Hasil penelitian juga menunjukkan nilai yang signifikan dari pengaruh kedua konstruk ini.

Bagi Manajemen PT Honda Dewata Motor, hasil penelitian ini dapat dijadikan sebagai sebuah tambahan informasi dalam menyusun strategi bisnisnya, khususnya dalam strategi relationship marketing. 
Hasil peneltian ini juga menunjukkan bahwa pentingnya bagi perusahaan untuk menjaga hubungan jangka panjang dengan pelanggan yang ada saat ini. Perusahaan disarankan untuk lebih memfokuskan pada pemuasan kebutuhan pelanggan yang sudah ada, dan menerapkan strategi relational benefits sebagai salah satu metode alternatif.

Pemberian perlakuan spesial memang belum menunjukkan hasil yang signifikan, walaupun terdapat indikator yang tidak berada pada rentang baik dan secara keseluruhan pelanggan masih puas, perusahaan harus tetap waspada dan berbenah serta mulai mencoba dan menyusun ulang strategi ini dengan lebih baik. Ini agar nantinya dapat menghadapi persaingan dan mengatasi seluruh kebutuhan pelanggan yang telah ada saat ini.

Dalam penelitian ini, konstruk special treatment benefits tidak berpengaruh secara signifikan kepada konstruk kepuasan dan juga loyalitas. Penelitian berikutnya sebaiknya jika ingin meneliti di perusahaan jasa yang sejenis, agar mengevaluasi dan mencari tambahan referensi untuk indikator-indikator yang membentuk konstruk special treatment benefits.

Topik penelitian mengenai relationship marketing khususnya relational benefits belum banyak dilakukan di Indonesia khususnya di Bali. Oleh karena itu, peluang penelitian sangat terbuka karena masih banyak jenis-jenis perusahaan lain yang dapat di teliti dengan pendekatan strategi relationship marketing khsusnya relational benefits.

Hasil dari penelitian ini diharapkan dapat memberikan manfaat secara praktis maupun teoritis mengenai strategi relationship marketing khususnya relational benefit, dan kaitannya dengan kepuasan serta juga loyalitas pelanggan PT Honda Dewata Motor. Secara teoritis penjabaran relationship marketing menekankan pada bagaimana membangun hubungan jangka panjang dengan pelanggan sehingga terdapat suatu manfaat bagi kedua belah pihak yaitu pelanggan dan juga perusahaan yang menerapkan strategi ini. Dengan strategi relational benefit melalui confidence benefits, social benefits, dan special treatment benefits diharapkan perusahaan mampu dalam menjaga hubungan baik dengan pelanggan.

Berdasarkan pemetaan distribusi jawaban responden, khususnya mengenai penilaian responden terhadap indikator-indikator konstruk diperoleh hasil sebagai berikut. Konstruk confidence benefits seluruh indikatornya berada pada rentang nilai baik. Hal ini menunjukkan bahwa secara umum perusahaan telah mampu mengaplikasikan strategi confidence benefits dengan baik dan hal tersebut harus dipertahankan bahkan ditingkatkan. Konstruk social benefits seluruh indikator memperoleh nilai baik, yang artinya perusahaan mampu membangun hubungan sosial yang baik dengan pelanggan PT Honda Dewata Motor. Akan tetapi, perusahaan tidak boleh berdiam diri dan puas dengan hasil yang ada sebab pesaing juga akan terus meningkatkan kualitas perusahaannya dan sewaktu-waktu dapat merebut pelanggan yang dimiliki oleh PT Honda Dewata Motor. Konstruk special treatment benefits tidak semua indikator mendapatkan nilai baik, tetapi terdapat satu indikator yang memperoleh nilai yang berada kategori cukup. Hal ini menunjukkan perlu usaha yang lebih baik lagi dari PT Honda Dewata Motor untuk dapat memberikan perlakuan istimewa kepada pelanggan. Hal ini juga sebagai sebuah peringatan bahwa perusahaan harus memperbaiki kinerjanya di dalam memberikan suatu manfaat khusus atau spesial kepada pelanggannya.

\section{Daftar Referensi}

Alrubaiee, L., \& Nahla, A. N. (2010). Investigate the impact of relationship marketing orientation on customer loyalty: The customer's perspective. International Journal of Marketing Studies, 2(1), 155-174.

Amonini, C., McColl-Kennedy, J. R., Soutar, G. N., \& Sweeney, J. C. (2010). How professional service firms compete in the market: An exploratory study. Journal of Marketing Management, 26(1), 28-55.

Ardyansyah. (2007). Pengaruh relational benefit dan relationship quality pada relational outcomes di PT ESC Indonesia. Tesis. Yogyakarta: Program Magister Manajemen UGM Yogyakarta.

Delcourt, C., Gremler, D. D., Van Riel, A. C. R., \& Van Birgelen, M. (2013). Effects of perceived employee emotional competence on customer satisfaction and loyalty. Journal of Service Management, 24(1), 5-24.

Dimitriadis, S. (2010). Testing perceived relational benefits as satisfaction and behavioral outcomes drivers. International Journal of Bank Marketing, 28(4), 297-313.

Eisingerich, A. B., \& Bell, S. J. (2006). Relationship marketing in the financial service industry. Journal of Financial Service Marketing, 10(4), 8697.

Ferdinand, A. (2002). Structural equation modeling dalam penelitian manajemen aplikasi modelmodel rumit dalam penelitian untuk tesis magister \& disertasi doktor. Semarang: BP UNDIP.

Gaur, S. S., Xu, Y., Quazi, A., \& Nandi, S. (2011). Relational impact of service providers' interaction behavior in healthcare. Managing Service Quality: An International Journal, 21(1), 67-87.

Hennig-Thurau, T., Gwinner, K. P., \& Gremler, D. D. (2002). Understanding relationship marketing 
outcomes: An integration of relational benefits and relationship quality. Journal of Service Research, 4(3), 230-247.

Hurriyati, R. (2005). Bauran pemasaran dan loyalitas konsumen. Bandung: Alfabeta.

Kau, A. K., \& Elizabeth, W. Y. L. (2006). The effect of service recovery on satisfaction: A comparison between complaints and non-complaints. Journal of Service Marketing, 20(2), 101-111.

Kim, H. D. (2005). The relationships between service quality, customer satisfaction, and repurchase intention in Korean private golf courses. Retrieved on April 1, 2014 from http://gradworks.umi. com/31/77/3177086.html.

Kinard, B. R., \& Capella, M. L. (2006). Relationship marketing: The influence of consumer involvement on perceived service benefits. Journal of Services Marketing, 20(6), 359-368.

Kotler, P. (2006). Manajemen pemasaran. Edisi kesebelas. Jilid II. Jakarta: Indeks Kelompok Gramedia.

Leverin, A., \& Liljander, V. (2006). Does relationship marketing improve customer relationship satisfaction and loyalty? International Journal of Bank Marketing, 24(4), 232-251.

Macintosh, G., \& Lockshin, L. S. (1997). Retail relationship and store loyalty: Multi-level perspective. International Journal of Research in Marketing, 14(5), 487-497.

Maria-Eugenia, M., Gil-Saura, I., \& BerenguerContri, G. (2009). Relational benefits and loyalty in retailing: An inter-sector comparison. International Journal of Retail \& Distribution Management, 37(6), 493-509.

Molina, A., Martin-Consuegra, D., \& Esteban, A. (2007). Relational benefits and customer satisfaction in retail banking. International Journal of Bank Marketing, 25(4), 253-271.

Navarro, M. M., Iglesias, M. P., \& Torres, P. R. (2004). The benefits of relationship marketing for the customer and for the fashion retailers. Journal of Fashion Marketing and Management, 8(4), 425-436.
Ndubisi, N. O., \& Chan, K. W. (2005). Factorical and discriminant analyses of underpinnings of relationship marketing and customer satisfaction. International Journal of Bank Marketing, 23(7): 542-557.

Palmatier, R. W., Dant, R. P., Grewal, D., \& Evans, K. R. (2006). Factor the influencing the effectiveness of relationship marketing: A meta analysis. Journal of Marketing, 70, 136-153.

Prayustika \& Adriani, P. (2010). Pengaruh manfaat relasional dan kualitas hubungan pada hasil pemasaran relasional di Bali Beach Golf Course, Tesis. Bali: Program Magister Manajemen Universitas Udayana Bali.

Semadi, L. P. S. W., Suprapti, N. W. S., \& Nurchaya, K. (2010). Pengaruh manfaat relasional terhadap kepuasan dan loyalitas nasabah bank (Studi kasus pada Bank BPD Bali cabang utama Denpasar). Bali: Program Magister Manajemen Universitas Udayana Bali.

Solimun (2005). Structural equation modeling. Surabaya: Universitas Katolik Widya Mandala.

Sugiyono (2009). Metode penelitian bisnis. Cetakan Kesepuluh. Bandung: CV Alfabeta.

Vincent, N. A., \& Cynthia, M. W. (2013). Exploring relationship marketing in membership associations. European Journal of Marketing, 47(10), 1622-1640.

Yen, H. J. R., \& Gwinner, K. P. (2003). Internet retail customer loyalty. Journal of Service, 14(5), 483-500.

Yen, T. F., Liu, H. H. J., \& Tuan, C. L. (2009). Managing relationship effort to influence loyalty: An emperical study on the sun link sea forest and recreational park, Taiwan. The International Journal of Organizational Innovation, 2(2), 179194.

Zheithaml, V. A., Bitner, M. J., \& Gremler, D. D. (2006). Service marketing: Integrating customer focus across the firm. $4^{\text {th }}$ Edition. New York: McGraw Hill. 